\title{
«Tør virkelig en læge vove at negte en patient kognak?!» - legenes reseptforskrivning i forbudstiden 1916-26
}

\begin{abstract}
BAKGRUNN I Norge var det forbud mot omsetning av brennevin 1916-26 og hetvin 1917-23, en historisk periode som kalles forbudstiden. Legene var i denne tiden portvakter som regulerte folks adgang til alkohol, ettersom resept var eneste lovlige tilgang til hetvin og brennevin. Flere har ment at legene sviktet i denne rollen og undergravde den norske forbudspolitikken.
\end{abstract}

KUNNSKAPSGRUNNLAG Artikkelen er basert på en gjennomgang av artikler om alkoholspørsmålet i Tidsskrift for Den norske lægeforening.

RESULTATER Mange leger mente at alkohol hadde gunstige effekter på helsen, både til forebygging, lindring og kurasjon. Dessuten var få leger avholdsmenn og mange var motstandere av forbudslinjen, det gjaldt også medisinaldirektøren. Etter hvert skrev mange leger ut store mengder brennevin og hetvin. Men virkelige brennevinsdoktorer var det færre av. Sterke krefter innen legestanden arbeidet for rasjonering, dvs. at folk skulle få utlevert en viss mengde alkohol utenfor medisinens kontroll, men dette ble det aldri politisk gjennomslag for.

FORTOLKNING Legene hadde et ansvar for utglidningen og dermed for alkolholforbudets endelikt. Brennevinsdoktorene truet med å ødelegge standens rykte, og de mest skruppelløse ble ekskludert fra Legeforeningen. Størst ansvar for utviklingen på reseptområdet hadde likevel helsemyndigheter og politikere, som brukte altfor lang tid på å få på plass et effektivt regelverk.

Forbudstiden begynte som et midlertidig tiltak for å sikre ro og orden under den første verdenskrig, i desember 1916. Da innførte regjeringen et juleforbud mot salg av brennevin til nytelsesformål, men gjorde unntak for brennevin til tekniske, medisinske og vitenskapelige formål. Skulle folk få tak i brennevin til høytiden på legalt vis, måtte det skje som pasient hos legen. Han hadde adgang til å skrive ut slikt på resept. Juleforbudet 1916 ble forlenget to ganger ved kongelig resolusjon vinteren 1917. I mai 1917 ble det til en midlertid lov, og i 1921 til varig forbud. Men det kom ikke til å bestå, fra 1. januar 1927 kunne brennevin igjen omsettes lovlig. Forbudet mot hetvin hadde en enda kortere historie: midlertidig forbud i mai 1917, varig forbud i 1921 og fritt tilgjengelig igjen fra senvinteren 1923. Men én konsekvens av forbudstiden består fremdeles. Vinmonopolet ble opprettet i 1922, og fra 1. januar 1923 skulle all import av vin og brennevin samt omsetning av svakvin foregå der.

Helt frem til slutten av 1800-tallet hadde alkohol stor utbredelse som legemiddel $\mathrm{i}$ Norge $(1,2)$. Vitenskapelige analyser kunne imidlertid i liten grad påvise positiv effekt av alkohol som forebyggende og kurerende middel ved sykdom. Etter hvert som det kom nye og alternative medikamenter, avtok legers anvendelse og anbefaling av brennevin som medisin. Da forbudstiden inntrådte, ble spørsmålet på bemerkelsesverdig vis både aktualisert og satt på spissen, og det viste seg at det innen legestanden fremdeles hersket ulike syn på dette.

I denne artikkelen skal vi se nærmere på rollen legene spilte som portvakter inn til alkoholens fristelser i forbudstiden - ikke til ølet og svakvinen, men til de sterkere saker. Fulgte norske leger opp myndighetenes forventninger til dem? I hvilken grad bidro legers reseptmisbruk til å undergrave forbudet?

\section{Kunnskapsgrunnlag}

Det har vært skrevet mye om forbudstiden, et tema i norsk historie som i ettertid er sett på som ganske eksotisk. Få har imidlertid studert hvilken rolle legene spilte under forbudet. Kriminologen Per Ole Johansen har relativt summariske kapitler om legene og reseptforskrivning i to bøker $(3,4)$, mens historikeren Per Fuglum (1924-2008) har mer utførlige bidrag $i$ et verk om alkoholforbudets historie i Norge (5).

Vår artikkel bygger på en gjennomgang av artikler om alkoholspørsmålet i Tidsskrift for Den norske lageforening i perioden 1916-26. Dette materialet gir en dypere innsikt i legenes rolle som alkoholforskrivere og deres syn på alkohol som medisin. Myndighetenes bestrebelser på å regulere alkoholforskrivningen er behandlet $i$ en annen artikkel (6).

\section{Legenes rolle i forbudstiden}

Legens nye rolle som portvakt kom nokså brått på. Mens 1916-årgangen av Tidsskrif-

\author{
Per Eivind Hem \\ per.hem@vikenfiber.no \\ Solbergliveien 19 \\ 0671 Oslo
}

\section{Erlend Hem}

Tidsskrift for Den norske legeforening

Engelsk oversettelse på www.tidsskriftet.no 


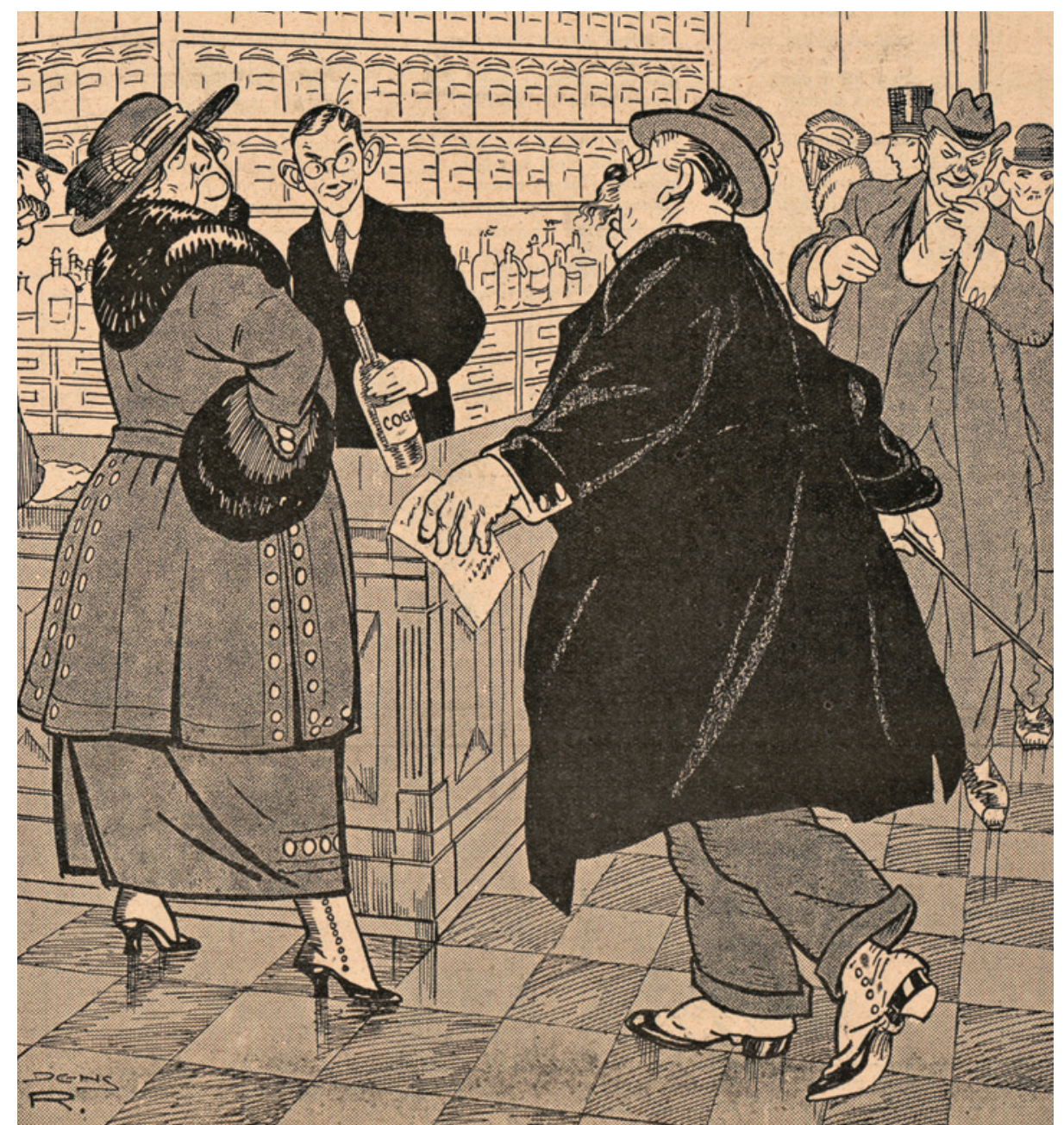

Figur 1 Til langt ut på 1900-tallet var det en uskarp grense mellom alkohol som nytelsesmiddel og som medikament. Her har tegneren Jens R. Nilssen (1880-1964) fremstilt en episode fra apoteket i vittighetsbladet Hvepsen nr. 9/1921. Verk av @ Jens R. Nilssen/BONO

tet ikke inneholdt noe om leger og brennevinsresepter, sto det i 1917 og de følgende år en rekke artikler om dette. Legenes rolle under brennevins- og hetvinsforbudet ble et sentralt tema for Legeforeningen og Tidsskriftet.

Dersom det var blitt innført et tilsvarende forbud mot alkohol i vår tid, ville det ikke berørt legene mer enn andre yrkesgrupper. Det skyldes at brennevin og hetvin ikke lenger regnes som medisin, bare som nytelsesmiddel, mens brennevinet i tidligere tider hadde en sentral plass i folks «medisinskap». Selv om forestillingen om den sterke drikks helsebringende virkninger etter århundreskiftet ikke sto like sterkt som før, var det i forbudstiden aldri aktuelt å sette en stopper for legers rett til forskrivning av brennevin til medisinsk bruk. Det myndighetene gjorde, var å innføre bestemmelser som skulle gjøre det vanskeligere å misbruke denne retten (6). For hetvinen var det litt annerledes. I august 1918, under spanskesykens herjinger, ble det faktisk innført forbud mot forskrivning av hetvin til medisinsk bruk. Men tiltaket ble bare en ubetydelig parentes i forbudets historie. Etter omfattende protester ikke minst fra legehold, ble helsemyndighetene tvunget til fullstendig retrett bare få uker senere (5, s. 121-2).

Grensen mellom alkohol som nytelsesmiddel og som medikament var uskarp (fig. 1). Man kan skille mellom tre medisinske indikasjoner. Noen leger mente en dram til maten, spesielt ved fete retter, var helsebringende. En del anerkjente den forebyggende effekten, at man tok seg en støyt ubehag. Da trengtes en flaske til husråd $\mathrm{i}$ «påkommende tilfeller». Endelig var det også leger som mente at alkohol kunne ha kurativ effekt på sykdom.

Hvis en lege før forbudet mente at pasienten burde behandles med alkohol, skrev han vanligvis ikke ut noen resept. Det var ikke nødvendig, folk kunne fritt kjøpe det de trengte uten å oppsøke apotek. For bruk av alkohol i forebyggende øyemed var også legen overflødig, dette var nærmest en del av den medisinske folketroen. Med ett ble altså denne type spørsmål brakt inn i legepasient-forholdet. I forbudstiden økte derfor antall legekonsultasjoner pga. kravet om resept, og de fleste reseptene gjaldt ganske sikkert alkohol i påkommende tilfeller. Tidligere hadde pasienten selv bestemt, nå hvis man kjente tendenser til kroppslig skulle legen avgjøre. Legen hadde ikke den naturlige autoriteten på dette feltet, slik han ellers hadde som fagmann med eksklusive kunnskaper om sykdommer og behandling. Det er ikke til å undres over at verken legen eller pasienten følte seg bekvem med den nye situasjonen.

\section{Legenes syn på alkohol som medisin} Legeforeningens generalsekretær, avholdsmannen Rasmus Hansson (1859-1934), som også var medredaktør av Tidsskriftet, skrev $i$ august 1917 at det var «meget faa indikationer til at forskrive spirituosa til medisinsk bruk» (7), og i en artikkel i november samme år la han til at alle måtte kunne være enige om at alkoholens betydning for å kurere sykdom var blitt stadig mindre (8).

Men så enkelt var det ikke. Norske leger var opptatt av problemstillinger knyttet til alkohol som medisin, og mange la avgjørende vekt på folks tro på alkoholens helsebringende virkninger. I de norske medisinske tidsskriftene sto ikke alkoholmisbruk og virkningene av dette på dagsordenen, slik som i USA, der samarbeidet mellom legene og avholdsbevegelsen var langt tettere. Det norske medisinske miljøet synes å ha hengt lenger ved forestillingen om alkohol som en velegnet medisin enn i mange andre land (4, s. 58; 5, s. 121).

Høsten 1917 sluttet medisinaldirektør Michael Holmboe (1852-1918) seg til en nylig innhentet uttalelse av farmakologiprofessor Edvard Poulsson (1858-1935) om alkohol som medisin (9). Professoren mente at alkohol av og til kunne være nyttig som næringsstoff ved sykdommer der fordøyelsen var sterkt nedsatt. Ved alvorligere former for diabetes «er alkohol meget værdifuld både som næringsstof og som middel til at gjøre den ensformige fettkost mere smakelig». Også ved anoreksier av forskjellige slag kunne alkohol i små doser være positivt, som appetittvekker. Poulsson avsluttet uttalelsen med at det var fullt berettiget for legene å forskrive «det vante digestivum» alkohol til friske, særlig eldre, personer som var vant til å ta en dram til maten, gjerne til såkalt «rørig kost», dvs. kraftig, tungt fordøyelig mat. Også det sluttet medisinaldirektøren seg til (9).

Her sto lite om alkoholens negative helseeffekter. Tidsskriftets redaktør Rasmus Hansson og enkelte andre reagerte på dette med en dram til maten. Hansson viste til moderne forskning som gikk i rette med Poulssons oppfatning. Men Poulssons og Holmboes syn vakte ellers få motsigelser innen legekretser. Det var rimeligvis medisinaldirektørens signaler de fleste leger lyttet til, og ikke avholdsmannen Hanssons formaninger.

Norske leger sto imidlertid mer splittet i synet på alkoholens helsebringende virkninger enn den manglende offentlige debatten hittil hadde kunnet tyde på. Det ble klart da spanskesyken rammet sommeren 1918. 
Presset mot leger til å forskrive brennevin synes på kort tid å ha økt dramatisk. Aftenposten hevdet 16. juli på redaksjonell plass at det iallfall var én medisin som etter sikker erfaring hjalp og beskyttet bedre enn noen annen, nemlig konjakk (10).

Tre overleger ved Ullevål sykehus rykket samtidig ut og advarte mot bruken av konjakk, som pga. epidemien skulle ha fått en hittil «uhørt anvendelse som lægemiddel». Lyder Nicolaysen (1866-1927), Olaf Scheel (1875-1942) og Yngvar Ustvedt (1868-1938) mente at noen forebyggende virkning av konjakk kunne det ikke være tale om. Folk måtte heller prøve å beskytte seg ved å vaske hender og ansikt før hvert måltid og unngå kontakt med smittede personer. Om alkohol som kurativt legemiddel var de ikke like kategoriske, men mente at noen direkte positiv virkning på sykdom aldri var blitt bevist og var høyst usannsynlig (11).

Reaksjonene lot ikke vente på seg. Carl Stoltenberg (1865-1939) syntes de tre overlegenes uttalelse var riktige ord i riktig tid. Han hadde nettopp hatt en eldre herre på sitt kontor som forlangte konjakk. Da legen, som verken var avholdsmann eller forbudstilhenger, ikke kunne se noen grunn til å skrive ut resept, utbrøt mannen: «Tør virkelig en læge vove at negte en patient kognak?!» (12). Men de fleste innleggene var negative. Dr. Bjarne Eide (1869-1929) kalte utspillet til Ullevålslegene for «en anmasende og arrogant uforskammethet overfor den norske legestand» (13). Den innflytelsesrike professor i hygiene og bakteriologi Axel Holst (1860-1931) påpekte at dyreforsøk med enkelte smittestoffer hadde vist at det meget vel kunne være en forebyggende virkning av konjakk. «Hvorfor skal der da ikke kunne være tale om en tilsvarende virkning paa den spanske syke?» spurte han (14) (fig 2). Holst hadde mange kolleger med seg i dette synet på alkohol, som ikke synes å ha endret seg nevneverdig så lenge forbudet besto.

\section{Legenes holdning til portvaktrollen}

Selv om legene generelt var lite tilfreds med rollen de var tildelt i forbudstiden, var viljen til å ta belastningen klart større til å begynne med enn hva den siden ble. I mars 1918 sendte Legeforeningens styre en uttalelse til Sosialdepartementet der de sågar var positive til legenes oppgave som portvakt. I løpet av året snudde imidlertid stemningen. På det 17. norske landslegemøtet i september 1918 ble det etter skarp debatt (med 161 mot 9 stemmer) vedtatt et forslag fremsatt av Axel Holst som krevde legene fritatt for portvaktrollen. I stedet måtte det innføres et strengt begrenset rasjoneringssystem ledsaget av et opplegg med individuell kontroll. En legekomité ble nedsatt for å utarbeide et forslag (15).

Denne legekomiteen, med Axel Holst som leder og Legeforeningens president Stian Erichsen (1867-1953) som et av medlemmene, gikk inn for at det fortsatt skulle være adgang til å forskrive visse mengder brennevinsblandinger til den syke. I tillegg skulle det være anledning for ethvert voksent, skikkelig menneske å kjøpe en halv flaske brennevin eller en hel flaske hetvin annenhver måned $(16,17)$. Slik ville legene bli fritatt for det de opplevde som et press fra pasientene om å få skrevet ut alkohol som husråd. Men legekomiteens henstilling, sendt regjeringen i mars 1919, ble ikke fulgt. Hadde forbudsavstemningen et halvt år senere fått et annet resultat, er det godt mulig en eller annen variant av rasjonering ville blitt valgt (18).

I Tidsskriftet kom det innlegg fra leger som protesterte mot «lægernes umyndiggjørelse» (19). Alle restriksjonene og kontrollen knyttet til forskrivningen ga en uvant følelse av å bli holdt under oppsikt. Legene oppfattet reseptretten som nesten hellig, og et av benkeforslagene på landslegemøtet i september 1918 hadde vært en begjæring om at legenes reseptrett uavkortet ble opprettholdt - med andre ord uten innblanding fra helsemyndighetene. Det var å strekke strikken vel langt, og ble åpenbart oppfattet som lite realistisk av legene selv.

\section{Hva gjorde Legeforeningen?}

Legene og deres forening sto i en vanskelig posisjon. De ønsket å bli fritatt for å ha enerett til å skaffe befolkningen brennevin og hetvin på legalt vis som medisin. Etter hvert så de ingen annen måte å komme unna ansvaret på enn ved en viss liberalisering av alkoholpolitikken. Medisinaldirektøren, og i enda høyere grad Legeforeningens president, mente alkohol kunne være å anbefale til nokså mange slags lidelser eller påkjenninger. For avholdsorganisasjonene virket dette som en rød klut. Kunne man egentlig stole på legene?

Det var ikke så lett å tyde Legeforeningens tilsynelatende noe sprikende formuleringer. Når president Erichsen inntrengende henstilte legene om å følge forskriften av desember 1919 på ethvert punkt, betydde det at legene måtte sørge for å holde seg på matta og unngå skandaler. Brennevinsdoktorene satte legestanden $i$ et dårlig lys, men presidenten ville ikke gå lenger for å rydde opp i egne rekker enn til å ekskludere medlemmer som vakte anstøt med sin reseptforskrivning. Den videre forfølgelsen av slike leger måtte politi og rettsvesen ta seg av. Erichsen avviste i 1920 et forslag om å etablere en kollegial kontroll, altså en intern legejustis, som det fra legehold ved flere anledninger var tatt til orde for $(20,21)$.

I november 1920 omtalte Kristianialegen Rudolf Krefting (1860-1942) den utglidningen som hadde skjedd dette året. Han skammet seg over å tilhøre en stand som under forbudet var blitt så demoralisert, skrev han. Det var nå gått så langt at

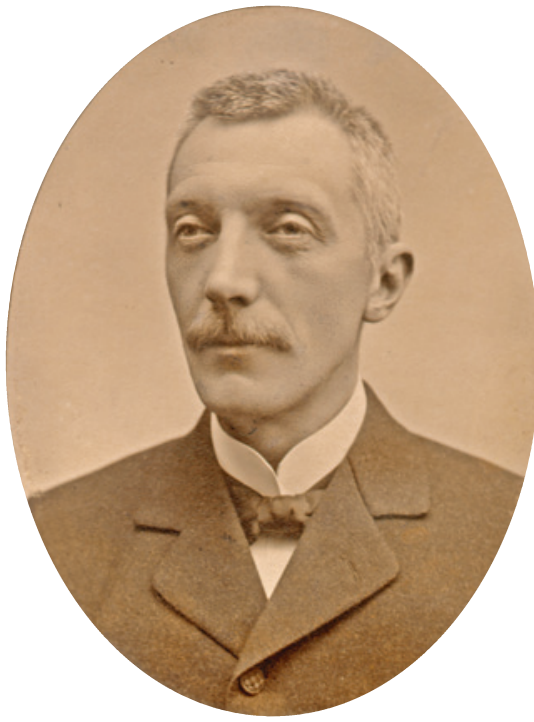

Figur 2 Axel Holst (1860-1931) var professor i hygiene og bakteriologi ved Universitetet i Kristiania samt bestyrer for universitetets hygieniske institutt 1893-1930. Han ledet den store Alkoholkommisjonen 1910-15, hvis innstilling med bilag fylte ca. 2500 sider. Holst var en dyktig forsker, men i synet på alkohol som medisin, var han mindre kritisk. Foto Ludvig Forbech, Universitetshistorisk fotobase ca. 1900

ikke bare et fåtall leger ble betegnet som brennevinsdoktorer, blant publikum ble «adskillige» karakterisert på den måten. Det ble sagt at man kunne få en lege til alt for penger. Dersom det fortsatte på samme måte, mente Krefting legene måtte forbys å forskrive alkohol. Han ba Legeforeningen eller Det medisinske selskap om å gripe tak i saken (22).

Krefting fikk svar fra Otto Mejlænder (1865-1944), lege i Trysil. Antakelig var det han og ikke Krefting som hadde flertallet av legene bak seg. Også han vedgikk at forholdene snart nærmet seg det «skamløse», men bebreidelsen burde rettes mindre mot legene enn mot den norske regjering, som hadde pålagt legene denne oppgaven. Han avviste Kreftings henstilling til Legeforeningen om å gjøre noe. Så sent som på landslegemøtet $\mathrm{i}$ august 1920 hadde Legeforeningens president advart forsamlingen mot «at gjøre sig til nar» ved å formulere noen ny resolusjon i alkoholspørsmålet den forrige fra vinteren 1919 hadde jo falt aldeles på steingrunn (23).

De fleste legene i Kristiansand samlet seg om et annet alternativ (24). Ettersom det var så vanskelig å vite hvor grensene burde gå for å anvende alkohol som medisin, besluttet de kun unntaksvis å utstede slike resepter. $\mathrm{Og}$ de få som ble utstedt, skulle det ikke tas betaling for. Generalsekretær og redaktør Hansson ble begeistret og appellerte til legestanden om å følge disse legenes eksempel $(25,26)$. Når det ble gratis med resept, ville pågangen bare øke, var det andre som mente, deriblant overlege Olaf Scheel (27). 


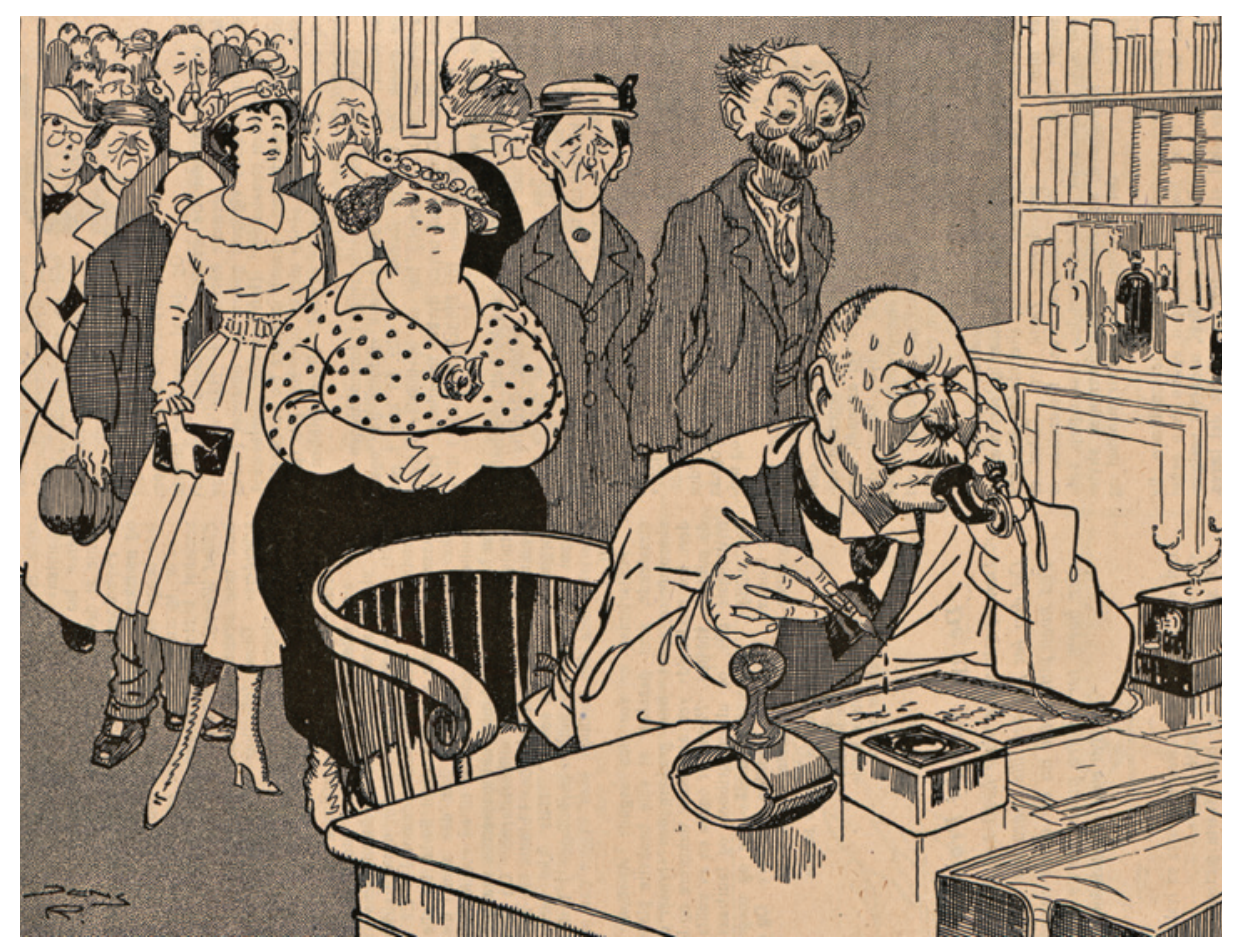

Figur 3 Legen Gustav Michelsen (1862-1926) skrev ut over 48000 brennevinsresepter i 1923. Han toppet listen over brennevinsdoktorer, som var betegnelsen på leger som misbrukte reseptretten i egen økonomisk vinning. Her har tegneren Jens R. Nilssen (1880-1964) fremstilt en brennevinsdoktor i vittighetsbladet Hvepsen allerede inr. 35/1917. Teksten lød slik: «Doktoren: Ligger han for døden, sier De? Ja, det faar ikke hjelpe, jeg har andet at bestille nu i syltetiden.»Verk av @ Jens R. Nilssen/BONO

Det var en utbredt oppfatning blant norske leger om at det burde lages et skille mellom resept til husmedisin og resept ved påvist sykdom. Den første gruppen var den som skapte krav og etterspørsel fra publikum, den sistnevnte var legenes sakkyndige gebet. Derfor var det ikke underlig at landslegemøtet i 1920 enstemmig vedtok at alkohol som husmedisin på resept var utilfredsstillende for både publikum og legene.

I mars 1920 påpekte Trondhjems Adresseavis at det var vanskelig å ramme brennevinsdoktorene ad rettens vei (28). Derfor ble spørsmålet om hva legestanden selv ville gjøre for å stoppe trafikken, stadig mer presserende. Halfdan Bryn (1864-1933), president i Legeforeningen 1921-22, svarte ved å marginalisere og demonisere brennevinsdoktorene. Samtidig skrøt han av legestanden som som helhet betraktet hadde greid den store påkjenningen den hadde vært utsatt for som følge av den gjeldende alkohollovgivningen. Han avsluttet innlegget med å bagatellisere situasjonen og med å sende et spark til forbudstilhengerne: $« \mathrm{Og}$ skulde alle de læger sættes i gapestokken, som efter forbudsfanatikernes mening har forsyndet sig, er jeg ræd for, at der ikke blev saa ret mange skikkelige læger igjen.» (29).

\section{Legene som undergravere av forbudet?}

Det er på det rene at få leger var avholdsmenn (30). Når legenes forslag til løsning var en form for rasjonering av brennevin, slik at de skulle slippe å skrive ut resepter i påkommende tilfeller, ble de uvegerlig uglesett av forbudets mest innbitte forsvarere. Det utviklet seg et sterkt spenningsforhold mellom flertallet av legene og avholdsmenn som Scharffenberg og Hansson. I 1922 sto en rekke innlegg i Tidsskriftet som nærmest dannet en kampanje mot bladets omfattende dekning av alkoholspørsmålet. Dels ble Hansson anklaget for å være ensidig og mangle objektivitet, dels ble det hevdet at spørsmålet for lengst var utdebattert $(30,31)$. Hansson påpekte at Legeforeningen ikke bare skulle hevde standsinteresser, men også legge vekt på de sosialmedisinske emnene som legene daglig kom i berøring med.

Ikke bare var det få avholdsmenn blant legene, mange var motstandere av forbudslinjen og hevdet alkoholens velsignelser som medisin. Men var det grunn god nok til å stemple standen som illojal mot myndighetenes alkoholpolitikk? Ifølge Johan Scharffenberg var legene «vore farligste fiender næst efter alkoholkapitalisterne og deres leiesvende» (32). Historikeren Per Fuglum mente at spesielt legene bidro til å undergrave det norske forbudet $\mathrm{i}$ den mest kritiske fasen. Han la vekt på «den overveiende skepsis» mot forbudet og «de skandaløse misbruk» som ble avdekket fra enkelte legers vedkommende $(5$, s. 436,620$)$ (fig 2$)$.

Legeforeningen var tidlig på banen og fordømte brennevinsdoktorene. Men for forbudstilhengerne var det sikkert forstemmende å se f.eks. fremtredende medisinere som by- og sykehuslege Einar Onsum
(1876-1963) og dr.med. Harald Natvig (1872-1947) reagere med slikt raseri mot sosialminister Paal Bergs (1873-1968) reseptforskrift, som i desember 1919 innførte strengere forskrivnings- og kontrollrutiner. Natvig spurte i et innlegg i Aftenposten hvordan statsminister Gunnar Knudsen (1848-1928) for sin samvittighet kunne forsvare å stå i bås med Berg. Onsum skrev en dobbeltkronikk i Aftenposten om «Brændevin og hedvin som husmedicin». Folk som gikk vill i fjellet var, «naar de halvdøde af kuldevæde og slid naar frem til folk - takket være Paal Bergs omsorg - afskaaret fra at faa den medicin, der i øieblikket bedre end noget andet kan stive dem op og bringe livsaanderne tilbage igjen» (33, s. 233).

Det var også velkjent at den nye medisinaldirektøren i 1919, Harald Gram (1875-1929), var forbudsmotstander (34, s. 424). Man kunne selvfølgelig spørre om hvilken kraft en motstander av forbudsloven var villig til å legge i forfølgelsen av egne fagfeller som tøyde strikken. De legene som først og fremst kunne klandres var de 30-50 som etter hvert skrev ut store mengder alkohol på resept. De ble holdt nøye under oppsikt og mange av dem møtte sanksjoner og fikk irettesettelser fra helsemyndighetene. Flere ble også rettsforfulgt, selv om det sjelden førte til fellende dom (6).

\section{Avslutning}

Ved folkeavstemningen i oktober 1926 gikk $56 \%$ inn for å oppheve brennevinsforbudet, $44 \%$ gikk imot. Til tross for at den største belastningen for legene, byrden ved å forskrive alkohol til husmedisin, var fjernet i 1924, lå sannsynligvis andelen leger som stemte ja til opphevelse av forbudet over landsgjennomsnittet $(5$, s. $636-7 ; 32)$. Det kan ikke være tvil om at legene hadde et ansvar for utglidningen og dermed for alkolholforbudets endelikt. Etter hvert skrev mange leger ut store mengder brennevin og hetvin. Men virkelige brennevinsdoktorer var det få av, slike som kan sammenliknes med brennevinssmuglere og -selgere i forbudstiden. Det største ansvaret for utviklingen på reseptområdet må likevel tillegges helsemyndighetene, som ikke i tide maktet å lage et lov- og regelverk som fungerte, og Stortinget, som trengte tre lovproposisjoner i perioden 1921-23 for å få avgjort hvordan reseptloven skulle se ut (6).

\section{Per Eivind Hem (f. 1963)}

er statsviter og har utgitt biografiene Jørgen Løvland: vår første utanriksminister (Samlaget, 2005) og Megleren: Paal Berg, 1873-1968 (Aschehoug, 2012).

Forfatter har fylt ut ICMJE-skjemaet og oppgir ingen interessekonflikter. 


\section{Erlend Hem (f. 1970)}

er dr.med. og assisterende sjefredaktør i Tidsskriftet.

Forfatter har fylt ut ICMJE-skjemaet og oppgir ingen interessekonflikter.

\section{Litteratur}

1. Schiøtz A. Folkets helse - landets styrke, 1850-2003. Det offentlige helsevesen i Norge, 1603-2003. Bd. 2. Oslo: Universitetsforlaget, 2003 $222-3$

2. Steenhoff G. Alkoholens roll som läkemede genom tiderna och idag. I: Vogt R, red. Frihet sannhet: festskrift til Johan Scharffenberg. 70 årsdagen 23. november 1939. Oslo: Johnsen \& Nielsen boktrykkeri, 1939: 180-98.

3. Johansen PO. Brennevinskrigen: en krønike om forbudstidens Norge. Oslo: Gyldendal, 1985.

4. Johansen PO. Markedet som ikke ville dø: forbudstiden og de illegale akolholmarkedene i Norge og USA. Oslo: Rusmiddeldirektoratet, 1994.

5. Fuglum P. Brennevinsforbudet i Norge. Trondheim: Tapir, 1995

6. Hem PE, Hem E. Et regelverk fullt av smutthull legenes reseptrett i forbudstiden 1916-26. Tidssk Nor Legeforen 2012; 132: 2636-40.

7. Red. Lægers recepter paa brændevin og sprit «til medicinsk bruk». Læger betegnes som «brændevinsgauker». Apotekernes forhold. Tidsskr Nor Lægeforen 1917; 37: 728

8. Hansson R. Lægernes forhold til doseringen av alkohol. Tidsskr Nor Lægeforen 1917: 37. 937-8.

9. Brændevinsrecepterne HM. Tidsskr Nor Lægeforen 1917; 37: 885-9.

10. Den spanske syke. Aftenposten 16.7.1918, gjengitt Tidsskr Nor Lægeforen 1918: 38: 679-80.

11. Nicolaysen L, Scheel O, Ustvedt Y. Om kognak mot den spanske syke. Morgenbladet 17.7.1918, gjengitt i Tidsskr Nor Lægeforen 1918; 38: 680-1.
12. Grøn F. «Den spanske syke» og kognaken. Mor genbladet 18.7.1918, gjengitt i Tidsskr Nor Lægeforen 1918; 38: 681-3

13. Eide B. Konjak og spansk syke. Tidens Tegn 25.7.1918, giengitt i referanse Johansen PO. Markedet som ikke ville $d \varnothing$ : forbudstiden og de illegale akolholmarkedene i Norge og USA. Oslo: Rusmid deldirektoratet, 1994: 59

14. Holst A. Spansk syke og kognak. Morgenbladet 22.7.1918, gjengitt i Tidsskr Nor Lægeforen 1918. 38: $723-4$.

15. Alkoholspørsmaalet. Spørsmaalet om lægernes forskrivning av brændevin og hete vine behandlet paa landsmøtet. Tidsskr Nor Lægeforen 1918; 38 : 829-33.

16. Alkoholspørsmaalet. Alkohol til medicinsk bruk Forslag fra den norske lægeforenings komite til regler for lægers forskrivning av spirituosa til medicinsk bruk. Tidsskr Nor Lægeforen 1919; 39. 407-16.

17. Alkoholspørsmaalet. Alkohol til medicinsk bruk Forslag fra den norske lægeforenings komite til regler for lægers forskrivning av spirituosa til medicinsk bruk. (Forts.). Tidsskr Nor Lægeforen 1919: 39: 452-62

18. Figenschau KJ, Vogt R. Alkoholspørsmaalet. Spiritus, brændevin og sterk (het) vin til medicinsk bruk m. v. De «Midlertidige forskrifter» av 5te december 1919. Tidsskr Nor Lægeforen 1920; 40: 27.

19. Sellæg CA. Forskrivning av spirituosa til medicinsk bruk. Den norske lægestands umyndiggjørelse. Tidsskr Nor Lægeforen 1918; 38: 687-8.

20. Erichsen S. Lægernes alkoholforskrivning. Indledende foredrag paa lægemøtet i Trondhjem 1920. Tidsskr Nor Lægeforen 1920; 40: 812.

21. Onsum E. Alkoholspørsmaalet. Forslag fra landslægemøtets komite om forskrivning av spirituosa til medicinsk bruk. - Brændevin og hetvin ti «husmedicin». Tidsskr Nor Lægeforen 1920; 40 $65-6$.

22. Brændevinsdoktorer KR. Tidsskr Nor Lægeforen 1920; 40: 776-7.

23. Brændevinsdoktorer MO. Tidsskr Nor Lægeforen 1920; 40: 842-3.
24. Alkoholspørsmaalet. Tidsskr Nor Lægeforen 1921 ; 41: 118.

25. Red. Lægernes alkoholforskrivning - honorarspørsmaalet. Tidsskr Nor Lægeforen 1921; 41: 287-8.

26. Red. Lægernes alkoholforskrivning - honorarspørsmaalet. Tidsskr Nor Lægeforen 1921; 41: 335-6.

27. Scheel 0. Lægers alkoholforskrivning - honorarspørsmaalet. Tidsskr Nor Lægeforen 1921; 41: 323-4.

28. Receptskandalerne. Trondhjems Adresseavis 19.3.1921, gjengitt i Tidsskr Nor Lægeforen 1921; 41: 417-8.

29. Lægeforeningens præsident H. Bryn om samme sak. Trondhjems Adresseavis 21.3.1921, gjengitt i Tidsskr Nor Lægeforen 1921; 41: 418-9.

30. Holst HB. Alkoholspørsmaalet og vort tidsskrift. Aapent brev til hr. Generalsekretær Rs. Hansson fra doktor Blich Holst. Tidsskr Nor Lægeforen 1922; 41: 236-7, 293.

31. Grøn F. Alkoholspørsmaalet. Alkoholspørsmaalet og vort tidsskrift. Tidsskr Nor Lægeforen 1922; 42 332,430

32. Scharffenberg J. Brændevinsdoktorer og apotekbrændevin. Folket 3.5.1921.

33. Hem PE. Megleren: Paal Berg, 1873-1968. Oslo: Aschehoug, 2012.

34. Søbye E. En mann fra forgangne århundrer: overlege Johan Scharffenbergs liv og virke 1869-1965 en arkivstudie. Oslo: Oktober, 2010.

Mottatt 17.10.2012, første revisjon innsendt 5.11. 2012, godkjent 8.11. 2012. Medisinsk redaktør Are Brean. 